\title{
Service Learning by STEM Activity in Secondary School at Prachin Buri Province, Thailand
}

\author{
Jaruwan Chutrtong, Narumon Boonman, and Waradoon Chutrtong
}

\begin{abstract}
The two purposes of this study were: 1) to explore the effects of one-time service learning on the cognitive and affective development of science undergraduates student of Suan Sunandha Rajabhat University and 2) to evaluate the effectiveness of STEM using on students' engagement in academic services. These questions were explored by means of qualitative study of 130 (grade 10-12) students of KrokSombunwittayakom School and 21 industrial microbiology students of Suan Sunandha Rajabhat University who participated in one-time service learning at Prachin Buri Province in 2016 and 2017. The study discussed in this article examined the benefits of service-learning using both questionnaire and interview data. From data analyses, it indicated that activity participants engaged in activities actively and mindfully. STEM, significantly, influenced students behavior. Service participation showed positive effects to students' performance. The positive effects of service can be explained by the fact that participation in service increases their experiences.
\end{abstract}

Index Terms-Service learning, Secondary school, STEM, Thailand.

\section{INTRODUCTION}

Service learning (SL) or community engagement pedagogies is an educational approach that combines learning objectives with community service in order to provide a pragmatic, progressive learning experience while meeting societal needs [1]. This concept derives from "learning by doing" which was popular in USA in the era of 60-70 [2]. It is also promotes in Latin America and many European countries. In countries with strong educational systems, higher education institutions integrate learning with the form of service learning [3]. The service-learning in USA is now actively as part of the core curriculum [4]-[6].

Service learning is widely accepted and applied to alternative learning in higher education institutions because it is the method that claimed to enhance student growth and the common good. It also claimed to enrich the learning experience [7]. The benefits that students will receive from the service learning are better learning outcomes, better personal outcomes and better social outcomes. Students will able to apply what they have learned in the real situation. They will able to analyze and solve problem. They will have greater sense of personal efficacy, personal identity, spiritual

Manuscript received October 9, 2018; revised May 13, 2019. This work was supported in part by Sunandha Rajabhat University, Thailand. Paper titles should be written in uppercase and lowercase letters, not all uppercase.

The authors are with the Sunandha Rajabhat University, Bangkok, 10300, Thailand (e-mail: jaruwan.ch@ssru.ac.th, narumon.bo@ssru.ac.th, waradoon@swu.ac.th). growth, and moral development. To live with others, students will have greater interpersonal development. They will able to work well with others, and build leadership and communication skills. In social part, students who joy in service learning activity will improve social responsibility and citizenship skills. On the other hand, community also benefited from this activity. It will enhance community-university relations. Student participation is the channel to apply new knowledge or innovation to community.

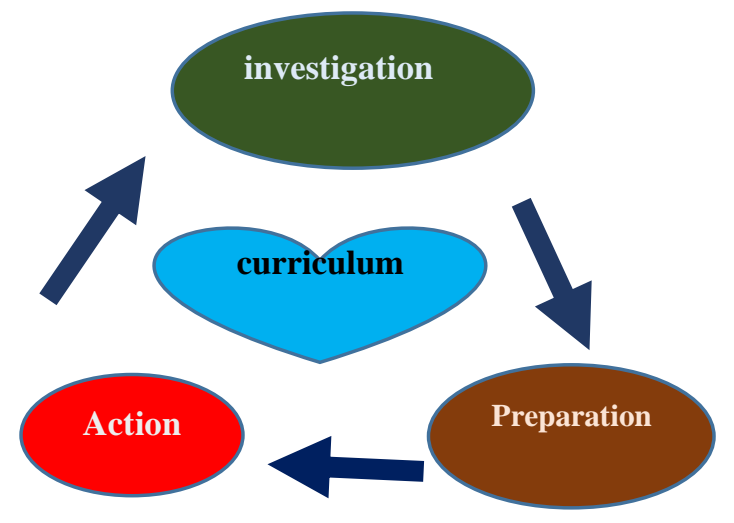

Fig. 1. Service learning pattern.

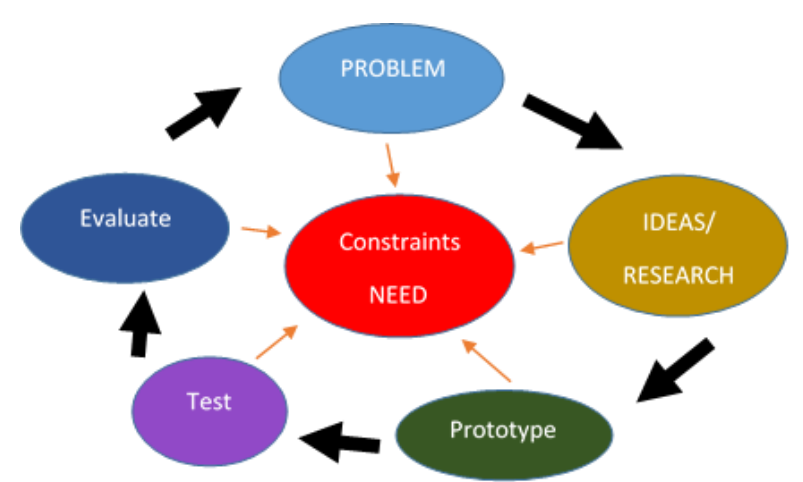

Fig. 2. STEM education model.

In Thailand, social services are defined as one of educational institutions duty by government policy. Some university integrate service learning into the curriculum of different subjects but most are organized as extra activities [8]. Social services by science students are activities that need to be done too. Nowadays, STEM (science, technology, engineering and mathematics) education is the model for scientific teaching. STEM integrates four specific disciplines into a cohesive learning paradigm based on real-world [9].

This model makes it possible for all learners to develop all aspects for being a quality person of the 21 st century. If the STEM model is used to organize service learning activities of science subjects, the results should be better. This research aims to find out the effects of STEM in a Service-Learning 
activity which operate by industrial microbiology students of Suan Sunandha Rajabhat University, Thailand. This paper reports an assessment of using STEM in a Service-Learning. We were interested to see whether advantages could be shown.

\section{PROCEDURE}

\section{A. Apply Service-Learning Theory to the Activity}

Service-learning applications vary depending on the detail of activity content and the area. Service-learning combine community need into the curriculum, giving students real-world learning experiences while providing benefit for the community. Four major objectives are realize to achieve quality service-learning: duration and intensity, links to curriculum, partnerships, and meaningful service.

\section{B. Designate the Activity}

Industrial microbiology department of Suan Sunandha Rajabhat University (SSRU) is a government education institution which teaches in variety of fields including arts, social science, business, education, sciences and technology major. The service-learning activity took place at KrokSombunwittayakom School, a small secondary school in Prachin Buri Province Thailand. Most KrokSombunwittayakom students are from rural areas. The study design for examining students' transformation after participation. I2 industrial microbiology students and 45 student in grade 11-12 of KrokSombunwittayakom School participated in 2016, the first year. In 2017, the participant of activity are 9 industrial microbiology students and 85 student in grade 10-12 of KrokSombunwittayakom School.

\section{Microbiology Concerns Products Service-Learning Activity}

Most students from rural area in Thailand do not go to higher education. So, current Thai government has policy for education organization to provide knowledge that is beneficial to life and can be career. One-time group service activity was held to achieve the objectives of the government and to serve service learning.

The authors of the accepted manuscripts will be given a copyright form and the form should accompany your final submission.

\section{Data Analysis}

Methods for gathering data included on-site participant observation, document analysis, questionnaire and interview.

Data collected included reflective comments, course evaluations, and feedback from the director of KrokSombunwittayakom School, teachers, and students.

\section{FINDINGS}

\section{A. Participants' Information}

Two-year participant data is shown in the Table I.

B. Evaluation of Activities in Terms of Satisfaction, Understanding and Appliance
Evaluation of activities was done by giving the participants from KrokSombunwittayakom School a questionnaire about satisfaction, knowledge, and utilization.

TABLE I: SSRU PARTICIPANTS' INFORMATION

\begin{tabular}{|c|c|c|c|c|}
\hline \multirow{2}{*}{ Cohort Year } & \multirow{2}{*}{$\begin{array}{c}\text { Number of } \\
\text { student }\end{array}$} & \multicolumn{2}{|c|}{ Sex } & \multirow{2}{*}{ Age } \\
\hline & & Female & Male & \\
\hline 2016 & 12 & 8 & 4 & $20-22$ \\
\hline 2017 & 9 & 8 & 1 & $20-22$ \\
\hline \multicolumn{5}{|c|}{ TABLE II: SCHOOL PARTICIPANTS' INFORMATION } \\
\hline \multirow{2}{*}{ Cohort Year } & \multirow{2}{*}{$\begin{array}{c}\text { Number of } \\
\text { student }\end{array}$} & \multicolumn{2}{|c|}{ Sex } & \multirow{2}{*}{ Age } \\
\hline & & Female & Male & \\
\hline 2016 & 45 & 27 & 18 & $16-18$ \\
\hline 2017 & 85 & 4 & 42 & $15-18$ \\
\hline
\end{tabular}

TABLE III: EVALUATION OF ACTIVITIES IN 2016

\begin{tabular}{lc}
\hline \hline Survey categories & Mean, Standard Deviation \\
\hline Satisfaction with knowledge transfer & $4.93+/-0.64$ \\
Understand the knowledge & $4.85+/-0.55$ \\
Fully integrate with project activities & $4.79+/-0.46$ \\
Expected to apply the knowledge & $4.85+/-0.69$ \\
engender mutual support & $4.78+/-0.54$ \\
\hline \hline
\end{tabular}

TABLE IV: EVALUATION OF ACTIVITIES IN 2017

\begin{tabular}{lc}
\hline \hline Survey categories & Mean, Standard Deviation \\
\hline Satisfaction with knowledge transfer & $4.25+/-0.69$ \\
Understand the knowledge & $4.27+/-0.55$ \\
Fully integrate with project activities & $4.14+/-0.52$ \\
Expected to apply the knowledge & $4.06+/-0.83$ \\
engender mutual support & $4.13+/-0.61$ \\
\hline \hline
\end{tabular}

\section{Qualitative Assessment from KrokSombunwittayakom School's Members}

The director and teachers who observe the activity were invited for individual interviews. All agreed to participate. Each interview lasted for around 15 minutes. The interviews were audio-recorded on recorder and the recorded conversations were transcribed verbatim. The designed interview protocol was semi-structured and so some emerging questions were asked during the conversations. The following comments exemplify the ways in which student enhanced by this activity.

TABLE V: SCHOOL MEMBERS' REFLECTION

\begin{tabular}{ll}
\hline \hline Topic & \multicolumn{1}{c}{ Comment } \\
\hline Learning process & $\begin{array}{l}\text { This implementation has greatly affected on } \\
\text { students' interest and skills developing. } \\
\text { The content is not related to the high school } \\
\text { Knowledgeable }\end{array}$ \\
$\begin{array}{l}\text { curriculum, but it can be used in everyday life. } \\
\text { Students are more attentive to learning by doing. } \\
\text { Consciousness }\end{array}$ & $\begin{array}{l}\text { They are more interested in science and have better } \\
\text { skills in using basic equipment. } \\
\text { Although the content is rarely related to the level of } \\
\text { the course, it is useful to convey to intimate person. } \\
\text { The school is located in country and needs a lot of } \\
\text { development. It is good for school that has other } \\
\text { organizations host such activities to develop } \\
\text { students' potential. }\end{array}$ \\
\hline \hline
\end{tabular}

D. Qualitative Assessment from Suan Sunandha Rajabhat University Participants

The industrial microbiology students of Suan Sunandha 
Rajabhat University who participate in this activity in the role of academic service provider were individual interviews. Participants each year are different, not the same person. Information will be asked in 2 aspects. The first topic is asking about the operation. The second one is about participant perspective transformation. Each interview lasted for around 30 minutes. The interviews were audio-recorded on recorder and the recorded conversations were transcribed verbatim.
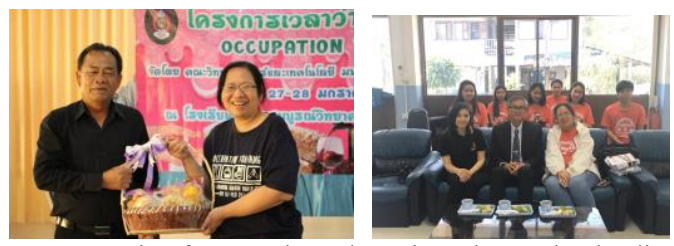

Fig. 3. Cooperation from KrokSombunwittayakom school's director.

TABLE VI: SSRU STUDENTS' TRANSFORMING

\begin{tabular}{ll}
\hline \hline $\begin{array}{l}\text { Transforming } \\
\text { Forms }\end{array}$ & \multicolumn{1}{c}{ Characteristics and Examples } \\
\hline Moral & $\begin{array}{l}\text { Unaltered } \\
\text { Can processed, delivered and answer questions to } \\
\text { the trainees. More ability to search information. } \\
\text { Sntellectual }\end{array}$ \\
Cultural & $\begin{array}{l}\text { and educational choices. } \\
\text { Emotional suspension. More discreet. }\end{array}$ \\
Personal & Act on privilege, power, and position. \\
\hline Working &
\end{tabular}

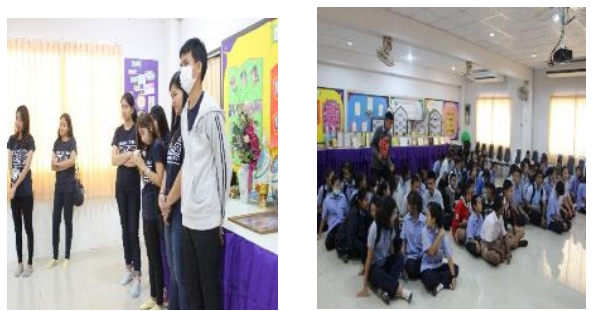

Fig. 4. Students from SSRU and KrokSombunwittayakom School: 2016's participants.
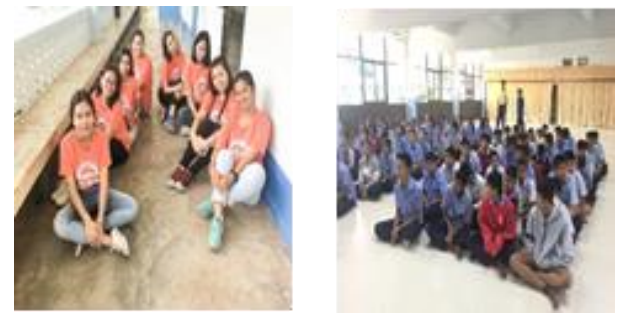

Fig. 5. Students from SSRU and KrokSombunwittayakom School: 2017's participants.

TABLE VII: SSRU STUDENTS' REFLECTION ON THE OPERATION

\begin{tabular}{|c|c|}
\hline Topic & Comment \\
\hline Planning & $\begin{array}{l}\text { Short period activities need to be tightened up. } \\
\text { Interesting activities make participants willing to attend. } \\
\text { Activities must be age appropriate. }\end{array}$ \\
\hline Equipment & $\begin{array}{l}\text { Equipment must be small amount and convenient to } \\
\text { carry. But it must be enough to use because school can't } \\
\text { support. }\end{array}$ \\
\hline Participants & $\begin{array}{l}\text { Participants enjoy activities but concentrate on limited } \\
\text { sessions. They didn't listen carefully. Some group hard } \\
\text { to control. }\end{array}$ \\
\hline Supporting & $\begin{array}{l}\text { University focus on activities by providing funding. The } \\
\text { teacher advise and recommend. The school also helps } \\
\text { during the activities. Activities are assisted throughout. }\end{array}$ \\
\hline Problem & $\begin{array}{l}\text { Personal problem, weather problems and surrounding } \\
\text { problems }\end{array}$ \\
\hline
\end{tabular}
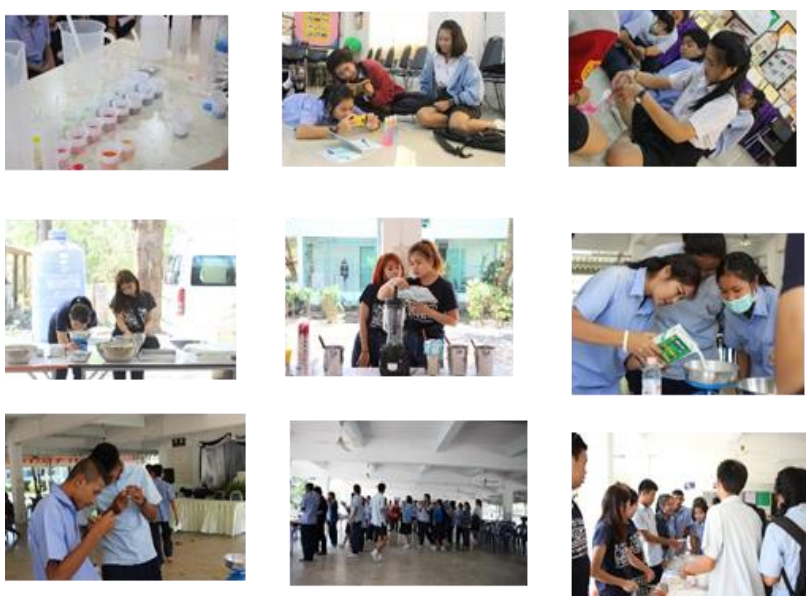

Fig. 6. Activity figure in 2016
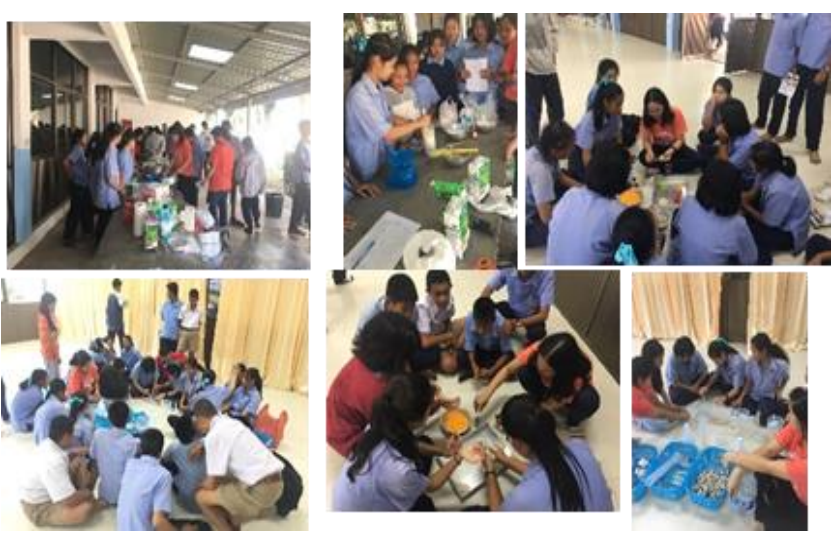

Fig. 7. Activity figure in 2017

\section{CONCLUSION}

This activities were held using STEM as tool because it was more directly measured. It also uses interviews and the responses from the questionnaire to assess the achievement of the activity. The evaluation showed that the provided activities were satisfied by the participants and the relatives. Activity knowledge is beneficial to the participants. Satisfaction in various aspects of the activity is more than 80 percent. This shows that STEM allows the learner to be interested and able to receive the information that teacher has set. This makes successful teaching. STEM is a way to stimulate interest for teenage participants. Teenagers in the digital age like learning by doing more than learning by the traditional way. Although the used method is interesting, there are other factors that affect the activity. The number of attending school's students in the first year was less than in second year while the number of university's in second year was less than in the first year. This inverse proportion is another factor in activity quality. Activities should have a balanced proportion of participants so that the activities will be thoroughly supervised.

Service learning for students in higher education is another way of learning, especially not content part. Service learning helps students learn in real-life situations. They face problems and solve problems by themselves. When students evaluated themselves, they found that participation in the activity caused some good changes. This research activity is one-time service, which is short period proceeding. Learning events was quite a little. The permanent transformation changes will 
not happen. Although service learning is encouraged to be part of a university course in America, to emerge undergrads as better community members, but it is not as prevalent in Asia. With a cultural difference, this kind of learning method still be difficult. At this time, In Thailand, management of service learning in course is still one-time project or option within a course. There are also financial factors involved.

\section{ACKNOWLEDGMENT}

The authors would like to thank president of Suan Sunandha University for his encouragement and thank director of KrokSombunwittayakom School for his assistance. And thanks to all the participants who are willing to participate.

\section{REFERENCES}

[1] J. M. Blakey, S. Theriot, M. Cazzell, and M. Sattler, "Is service-learning worth it?: A mixed-methods study of faculty's service-learning experiences," The International Journal of Service-Learning and Community Engagement, vol. 3, no. 1, July 2015.

[2] L. P. Tedesco and K. A. Salazar, "Using environmental service-learning in an urban environment to address water quality issues," Journal of Geoscience Education, vol. 54, pp. 123-132, May 2006.

[3] D. C. Kammler, T. M. Truong, G. VanNess, and A. E. McGowin, "A service-learning project in chemistry: Environmental monitoring of a nature preserve," Journal of Chemical Education, vol. 89, no. 11, pp. 1384-1389, October 2012.

[4] B. E. Moely, M. McFarland, D. Miron, S. Mercer, and V. Ilustre, "Changes in college student's attitudes and intentions for civic involvement as a function of service-learning experiences," Michigan Journal of Community Service Learning, vol. 19, no. 1, pp. 18-26, 2002.

[5] C. A. Young, R. S. Shinnar, R. L. Ackerman, G. P. Carruthers, and D. A. Young, "Implementing and sustaining service-learning at the institutional level," The Journal of Experiential Education, vol. 29, no. 3, pp. 344-365, September 2007.

[6] R. G. Bringle and J. A. Hatcher, "Institutionalization of service learning in higher education," Journal of Higher Education, vol. 71, no. 3, pp. 273-290, May/June 2000.

[7] P. L.Yorio and F. Ye, "A meta-analysis on the effects of service-learning on the social, personal, and cognitive outcomes of learning," Academy of Management Learning \& Education, vol. 11, no. 1, pp. 9-27, March2012.

[8] J. Chutrtong, "Activity beyond classroom enhance understanding of science," in Proc. 18th International Scientific Conference on Economic and Social Development - "Building Resilient Society"," 2016, pp. 412-416.

[9] D. C. Kammler, T. M. Truong, G. VanNess, and A. E. McGowin, "A service-learning project in chemistry: Environmental monitoring of a nature preserve," Journal of Chemical Education, vol. 89, no. 11, pp. 1384-1389, October 2012.

Copyright $@ 2019$ by the authors. This is an open access article distributed under the Creative Commons Attribution License which permits unrestricted use, distribution, and reproduction in any medium, provided the original work is properly cited (CC BY 4.0).

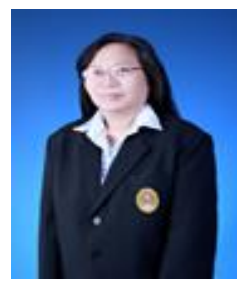

Jaruwan Chutrtong was born in Bangkok Thailand, on January 3, 1965. She got the bachelor degree: bachelor of science (B.Sc.) in biology (microbiology) from Srinakharinwirot university, Bangkok Thailand in 1985; the master degree: master of science (M.Sc.) in microbiology from Kasetsart University, Bangkok Thailand in 1994.

She worked as medical scientist in Regional Medical Sciences Center in Nakhon Ratchasima between1985-1988. In 1988-1994, she worked as MEDICAL SCIENTIST in Department of Medical Sciences, Ministry of Public Health in Bangkok. After that, from 1994 - now, she is LECTURER in industrial microbiology department, faculty of science and technology Suan Sunandha Rajabhat university, Bangkok Thailand. Previous publications:

1. J. Chutrtong, "Comparison of Corncob and Corn Using as Fungal Culture Medium," Procedia-Social and Behavioral Sciences, vol.197, pp. 797-800 2015 .

2. J. Chutrtong, "Survival of Probiotic Bacteria in Freeze-Dry Yogurt Starter Cultures Storage at 4 and 30 Degree Celsius," Procedia-Social and Behavioral Sciences, vol.191, pp. 2219-2225, 2015.

3. J. Chutrtong, "Activity beyond classroom enhance understaning of science," Economic and Social Development: Book of Proceedings, pp. 412-415, 2016.

Asst. Prof. Jaruwan Chutrtong: memberships - committee of Educational Professional Foundation.

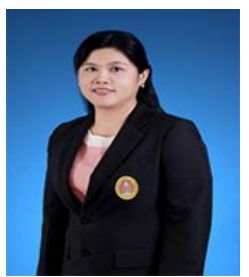

Narumon Boonman was born in Chuntaburi Thailand on April 26, 1980. She got the bachelor degree: bachelor of science (B.Sc.) in biology from Mahidol university, Bangkok Thailand in 2002; the master degree: master of science (M.Sc.) in microbiology from Mahidol university, Bangkok Thailand in 2007; the doctorate degree (Ph.D.) in microbiology from Mahidol University, Bangkok

Thailand in 2012

From 2012 - now, she is lecturer in Industrial Microbiology Department, Faculty of Science and Technology, Suan Sunandha Rajabhat University, Bangkok Thailand. Previous publications:

1. N. Boonman, S. Wiyakrutta, N. Sriubolmas and A. D. Chusattayanond "Acanthamoebicidal activity of Fusarium sp. Tlau3, an endophytic fungus from Thunbergia laurifolia Lindl.,"Parasitology Research, Vol 103, no.5, pp. 1083-1090, 2008.

2. N. Boonman, S. Prachya, A. Boonmee, P. Kittakoop , S. Wiyakrutta, N Sriubolmas, S. Warit and A. D. Chusattayanond, "In vitro acanthamoebicidal activity of fusaric acid and dehydrofusaric acid from an endophytic fungus Fusarium sp. Tlau3.," Planta Med, vol. 78, no.14, pp.1562-7, 2012.

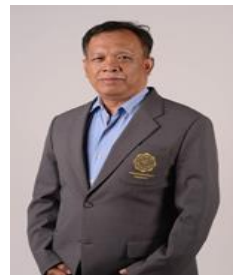

Waradoon Chutrtong was born in Bangkok Thailand on January 11, 1959. He got the bachelor degree: bachelor of science (B.Sc.) in chemistry from Ramkhamheng University, Bangkok Thailand in 1984; the master degree: master of science (M.Sc.) in chemistry (analytical) from Kasetsart University, Bangkok Thailand in 1995.

$\mathrm{He}$ worked as medical scientist in Regional Medical Sciences Center in Nakhon Ratchasima between 1986-1989. In 1989-1995, he worked as medical scientist in Department of Medical Sciences, Ministry of Public Health in Bangkok. After that, from 1995 - now, he is lecturer in Chemistry Department, Faculty of Science, Srinakharinwirot University, Bangkok Thailand. Asst. Prof. Waradoon Chutrtong: memberships - committee of Council of science and technology professionals. 